\title{
PENGARUH MEDIA EDMODO SEBAGAI BASIS E-LEARNING TERHADAP MOTIVASI BELAJAR SISWA PADA MATA PELAJARAN IPA
}

\author{
Iin Royani ${ }^{1) a)}$, Irham Falahuddin ${ }^{2)}$, Gusmelia Testiana ${ }^{3)}$ \\ ${ }^{1)}$ Prodi Pendidikan Biologi, Fak. Ilmu Tarbiyah dan Keguruan, UIN Raden Fatah Palembang \\ Jl. Prof. K. H. Zainal Abidin Fikri No. 1 A KM 3.5, Palembang 30126, Indonesia. \\ ${ }^{2)}$ Fakultas Sains dan Teknologi, UIN Raden Fatah Palembang \\ Jl. Prof. K. H. Zainal Abidin Fikri No. 1 A KM 3.5, Palembang 30126, Indonesia. \\ ${ }^{3)}$ Fakultas Sains dan Teknologi, UIN Raden Fatah Palembang \\ Jl. Prof. K. H. Zainal Abidin Fikri No. 1 A KM 3.5, Palembang 30126, Indonesia.
}

\section{a)Iinroyanibiologi.ir@gmail.com}

\begin{abstract}
This research is motivated by teacher-centered learning so that learning takes place in one direction and students have less chance to see real phenomenon or media related to the material. The reality on the ground shows that the media used by teachers in teaching is dominated by conventional media such as PPT and books. The purpose of this study was to determined the effect of Edmodo media as the basis of E-learning on students' learning motivation of science subjects. The sample of this research was students of VII.4 class (experiment) which amounted to 30 students and VII.3 class (control) which amounted to 33 students. Data collection techniques used a motivation level questionnaire. Data analysis used is statistical parametric test by using test with value $\mathrm{dk}=61$, significant level 0,05 obtained by tcount value equal to 5,539> ttabel 2,00. Based on the results of research, $\mathrm{H}_{1}$ accepted and $\mathrm{H}_{0}$ rejected means edmodo media as the basis of e-learning influence on students' learning motivation science subjects.
\end{abstract}

Keywords : Etmodo, e-learning, learning motivation, science

\section{PENDAHULUAN}

Sistem pendidikan Indonesia mengalami perkembangan seiring meningkatnya kebutuhan akan pendidikan yang berkualitas. Berbagai upaya dan alternatif pembelajaran diimplementasikan guna meningkatkan mutu pendidikan dari segala aspek, yang merubah sistem konvensional menjadi lebih relevan dengan kebutuhan yang makin kompetitif. Indonesia perlu mengenalkan dan mengimplementasikan konsep edukasi yang berputar di aktivitas yang beragam, programprogram yang bervariasi untuk menciptakan sebuah suasana pengembangan peserta didik yang baik (Sastroprawiro, 2011). Menurut Khodijah (2011) belajar merupakan suatu proses yang berlangsung sepanjang hayat, semua kecakapan, keterampilan, pengetahuan, kebiasaan, kegemaran, dan sikap manusia terbentuk, dimodifikasi dan berkembang karena belajar.

Di Era Globalisasi pembelajaran dengan pendekatan kontekstual sangat dianjurkan. Konsep pendekatan ini membantu guru untuk mengaitkan antara materi yang diajarkan dengan situasi dunia nyata siswa. Konsep pendekatan mendorong siswa membuat hubungan antara pengetahuan yang dimilikinya dengan penerapannya dalam kehidupan mereka sebagai anggota keluarga dan masyarakat. Sebagai contoh penggunaan smartphone tidak dapat dipisahkan dari kehidupan sehari-hari salah satunya siswa. Konsep pendekatan diharapkan siswa memiliki motivasi dalam belajar. Proses pembelajaran berlangsung alamiah dalam bentuk kegiatan siswa bekerja dan memahami bukan mentransfer pengetahuan dari guru ke siswa. Motivasi belajar lebih penting daripada hasil (Aqib, 2013).

Berdasarkan hasil observasi di salah satu SMP di Palembang, terdapat dua aspek penting saat proses pembelajaran berlangsung yaitu proses mengajar yang dilakukan oleh guru dan proses belajar yang dilakukan oleh siswa. Pada proses mengajar terlihat bahwa: media yang digunakan oleh guru dalam mengajar didominasi dengan penggunaan media kovensional, sehingga pembelajaran di kelas masih berpusat pada guru (teacher centered). Pada aktifitas siswa bahwa 
siswa kurang mampu membangun pengetahuannya sendiri dan lebih suka mendengar ceramah dari guru serta siswa merasa kesulitan apabila diminta mengulang kembali materi yang telah dipelajari. Berdasarkan observasi, sekolah ini sudah tidak asing lagi menggunakan alat-alat elektronik yang sebenarnya dapat digunakan untuk memberi motivasi lebih kepada siswa untuk belajar. Berdasarkan hasil angket prapenelitian dengan pertanyaan, "Apakah anda membawa handphone ke lingkungan sekolah?" 93\% dari respondeng menjawab "iya". Selain itu untuk pertanyaan, "Apaakah handphone yang anda gunakan memiliki fiture android/smartphone?" $89 \%$ dari 60 responden menjawab "iya".

Pembelajaran dengan menyesuaikan lingkungan selain menyelamatkan anak dari tindakan yang menyimpang dalam menggunakan teknologi diharapkan menambah motivasi belajar siswa, karena mereka merasa media yang digunakan dalam pembelajaran sangatlah update. Menurut Harjanto (2008) bahwa media adalah suatu ekstensi manusia yang memungkinkannya mempengaruhi orang lain yang tidak mengadakan kontak langsung dengan dia contohnya media komunikasi mencakup surat-surat, televisi, film, dan telepon. Menurut Gerlach dan Ely (dalam Arsyad, 2007) media apabila dipahami secara garis besar adalah manusia, materi, atau kejadian yang membangun kondisi yang membuat siswa mampu memperoleh pengetahuan, keterampilan atau sikap.

Azhar (2002) mengemukakan tiga ciri media yang merupakan petunjuk mengapa media digunakan untuk pembelajaran dan apa saja yang dapat dilakukan oleh guru terhadap media agar memiliki pengaruh yang efektif dalam pembelajaran. Tiga ciri dari media yang digunakan dalam pembelajaran yaitu ciri fiksatif, manipulatif, dan distributif. Ciri Fiksatif (Fixative Property) menggambarkan kemampuan media merekam, menyimpan, melestarikan, dan merekonstruksi suatu peristiwa atau objek yang dapat diurutkan dan disusun kembali contohnya media yang digolongkan seperti fotografi, video, tape, disket komputer, dan film. Suatu objek yang telah diambil gambarnya (direkam) dengan kamera atau video kamera dapat direproduksi dengan mudah kapan saja diperlukan. Ciri manipulatif (Manipulative Property) adalah transformasi suatu kejadian atau objek dimungkinkan karena media memiliki media manipulatif. Kejadian yang memakan waktu berhari-hari bahkan berbulan-bulan dapat disajikan kepada siswa dalam waktu dua sampai tiga menit dengam teknik pengambilan gambar time- lapse recording. Ciri Distributif (Distributive property dari media memungkinkan suatu objek atau kejadian ditransportasikan melalui ruang, dan secara bersamaan kejadian tersebut disajikan kepada sejumlah besar siswa dengan stimulus pengalaman yang relatif sama dengan mengenai kejadian itu. Distribusi media tidak hanya terbatas pada suatu kelas atau beberapa kelas pada sekolah-sekolah dalam wilayah tertentu, tetapi juga media itu, misalnya, rekaman video, audio, disket, dan video compact disk (VCD) dapat disebarkan ke seluruh penjuru tempat yang diinginkan kapan saja.

E-learning adalah pembelajaran jarak jauh (distance Learning) yang memanfaatkan teknologi komputer, jaringan komputer atau Internet (Prawiradilaga, 2013). Hal ini juga diungkapkan Naidu (2006) dalam Prawiradilaga (2013) yang mendefinisikan e-Learning sebagai penggunaan secara sengaja jaringan teknologi informasidan komunikasi dalam proses belajar dan mengajar. Istilah lain yang mengacu pada hal yang sama, yaitu online learning atau web based learning. ELearning memungkinkan pembelajar untuk belajar melalui komputer di tempat mereka masingmasing tanpa harus secara fisik pergi mengikuti pelajaran/perkuliahan di kelas dan memacu untuk melakukan kegiatan metode synchronous dan asynchronous pada $e$-Learning.

Menurut Yazdi (2012) e-Learning juga memiliki kelebihan dan kekurangan yaitu sebagai berikut: Kelebihan yaitu tersedianya fasilitas $e$ moderating dimana guru dan siswa dapat berkomunikasi secara mudah, guru dan siswa dapat menggunakan bahan ajar atau petunjuk belajar yang terstruktur dan terjadwal, siswa dapat belajar atau mengulang bahan ajar setiap saat, apabila siswa memerlukan tambahan informasi yang berkaitan dengan bahan yang dipelajarinya, ia dapat melakukan akses di internet secara lebih mudah, baik guru maupun siswa dapat melakukan diskusi melalui internet yang dapat diikuti dengan jumlah peserta yang banyak, sehingga menambah ilmu pengetahuan dan wawasan yang lebih luas, berubahnya peran siswa dari yang biasanya pasif menjadi aktif dan relatif lebih efisien.

Kekurangan dari pembelajaran e-learning antara lain kurangnya interaksi antara guru dan siswa atau bahkan antar siswa itu sendiri, kecenderungan mengabaikan aspek akademik atau aspek sosial dan sebaliknya mendorong tumbuhnya aspek bisnis/komersial, proses belajar dan mengajarnya cenderung ke arah pelatihan daripada pendidikan, berubahnya peran guru dari yang semula menguasai teknik pembelajaran 
konvensional, kini juga dituntut mengetahui teknik pembelajaran yang menggunakan ICT, siswa yang tidak mempunyai motivasi belajar yang tinggi cenderung gagal, tidak semua tempat tersedia fasilitas internet, kurangnya tenaga yang mengetahui dan memiliki ketrampilan internet, kurangnya penguasaan bahasa komputer. Ada berbagai jenis e-learning yang diterapkan di sekolah, namun salah satunya yaitu LMS atau Learning Management System. Edmodo merupakan salah satu jenis LMS yang sering digunakan saat ini (Suriadhi dkk., 2014).

Edmodo adalah platform media sosial yang sering digambarkan sebagai Facebook untuk sekolah dan dapat berfungsi lebih banyak lagi sesuai dengan kebutuhan. Edmodo merupakan aplikasi yang menarik bagi guru dan siswadengan elemen sosial yang menyerupai Facebook, tapi sesungguhnya ada nilai lebih besar dalam aplikasi edukasi berbasis jejaring sosial ini. Edmodo sangat komprehensif sebagai sebuah course management system seperti layaknya Moodle, dengan interface yang menyerupai facebook yang merupakan media sosial popular saat ini, penguna tidak akan merasa asing bahkan akan merasa mudah untuk menggunakannya. Edmodo dapat digunakan sebagai media pembelajaran untuk semua bidang studi yang tidak menggunakan aktivitas dan pengamatan secara langsung, IPA adalah salah satunya (Basori, 2013).

Motivasi merupakan salah satu aspek yang perlu diperhatikan guru agar siswa terlibat aktif dalam kegiatan belajar mengajar. Menurut Winkel (dalam Sardirman, 2005) motivasi berarti keseluruhan prestasi atau daya penggerak dalam diri individu yang menimbulkan kegiatan belajar dan menjamin kelangsungan belajar. Menurut Uno (2009), dapat diklasifikasikan antara lain adanya hasrat dan keinginan berhasil, adanya dorongan dan kebutuhan dalam belajar, adanya harapan dan citacita masa depan, adanya penghargaan dalam belajar, adanya kegiatan yang menarik dalam belajar, adanya lingkungan belajar yang kondusif.

\section{METODOLOGI PENELITIAN}

Penelitian ini dilaksanakan di salah satu SMP di Palembang pada bulan April 2017. Jenis penelitian yang digunakan adalah penelitian eksperimen semu atau quasi (Sugiyono, 2015). Desain penelitian quasi experiment yaitu dengan Non-equivalent Control Group Design (X adalah perlakuan dan $\mathrm{O}$ adalah observasi).

\begin{tabular}{lll}
\hline Kelas Eksperimen & $\mathrm{X}$ & $\mathrm{O}_{1}$ \\
Kelas Kontrol & - & $\mathrm{O}_{2}$ \\
\hline
\end{tabular}

Pada penelitian ini variabel yang diukur adalah motivasi belajar siswa kelas VII SMP. Peneliti menggunakan media Edmodo sebagai basis e-learning untuk media alternatif pada mata pelajaran IPA yang dikombinasikan dengan praktikum. Populasi atau wilayah generalisasi yang diteliti terdiri atas obyek/subyek yang mempunyai kualitas dan karakteristik tertentu yang ditetapkan oleh peneliti untuk dipelajari kemudian ditarik kesimpulan (Sugiyono, 2013). Populasi dalam penelitian ini adalah seluruh siswa kelas VII di salah satu SMP di Palembang pada semester ganjil tahun ajaran 2016/2017 berjumlah 342 siswa. Prosedur penelitian kelas eksperimen adalah: (1) tahap perencanaan dengan mempersiapkan rencana pelaksanaan pembelajaran (RPP), (2) tahap persiapan dengan mempersiapkan materi/bahan ajar. (3) tahap pelaksanaan dengan melakukan proses pembelajaran pada kelas eksperimen menggunakan media Edmodo sebagai basis $e$ learning. Pada kelas kontrol menggunakan media power point (PPT). Teknik pengumpulan data terdiri atas observasi, angket, dan dokumentasi.

\section{HASIL DAN PEMBAHASAN}

Pembelajaran menggunakan media Edmodo sebagai basis e-learning dengan media ppt mempunyai pengaruh yang berbeda jika dilihat dari nilai mean yang diperoleh. Mean kelas eksperimen adalah 79 sedangkan kelas kontrol 71 . Nilai ratarata yang diperoleh siswa dalam pembelajaran menggunakan media Edmodo sebagai basis $e$ learning adalah 79 sedangkan presentasenya adalah $7 \%$ dengan kategori tinggi berjumlah 2 orang dengan nilai 87 keatas. Presentase $80 \%$ untuk kategori sedang dengan jumlah siswa 24 orang dengan nilai antara 72-86. Kategori rendah dengan presentase $13 \%$ berjumlah 4 orang siswa. Pada saat proses pembelajaran berlangsung siswa sangat antusias dengan pembelajaran karena media yang digunakan terpenuhi, dan guru memberi kebebasan kepada siswa untuk mencari informasi sendiri dan berdiskusi. Nilai rata-rata yang diperoleh siswa kelas kontrol dalam pembelajaran menggunakan media PPT adalah 71 dengan presentase $6 \%$ termasuk kategori tinggi dengan jumlah 2 orang siswa dan rentang nilainya adalah 80 keatas. Presentase $88 \%$ dengan kategori sedang berjumlah 18 orang siswa dengan rentang nilai antara 63-79. Presentase $6 \%$ dengan jumlah 2 orang siswa masuk dalam kategori rendah dengan rentang nilai $62 \mathrm{ke}$ bawah.

Berdasarkan data posttest penilaian kinerja diperoleh nilai rata-rata utnuk kelas eksperimen 
sebesar 83,3 dan kelas kontrol sebesar 74 dengan banyak data 30 siswa. Berdasarkan uji normalitas, data sampel kedua kelas dinyatakan berdistribusi normal karena nilai signifikansi keduanya telah lebih dari 0,05 .

Kemudian berdasarkan uji hipotesis juga disimpulkan bahwa $\mathrm{H}_{1}$ diterima karena t-hitung > dari $\mathrm{t}$ - tabel. Oleh sebab itu, hipotesis kerja $\mathrm{H}_{1}$ diterima dan Ho ditolak. Hal ini berarti media Edmodo sebagai basis e-Learning berpengaruh terhadap motivasi belajar siswa pada mata pelajaran IPA Terpadu untuk siswa SMP kelas VII karena pembelajaran dengan menggunakan media edmodo memberikan pengalaman baru secara langsung kepada siswa.

Media Edmodo sebagai basis e-learning dapat digunakan untuk alternatif media pembelajaran yang inovatif dalam proses belajar karena pembelajaran dengan media ini menuntut siswa untuk belajar lebih aktif dan partisipatif, selain itu guru dituntut menguasai materi, kreatif, memahami karakteristik siswa, menghargai apa yang dilakukan/ jawaban siswa. Sikap guru yang ramah dan mengerti kondisi siswa menyebabkan siswa akan merasa nyaman dalam proses pembelajaran dan guru akan merasa nyaman dalam menyampaikan materi. Siswa diajak belajar dengan lebih aktif dengan melakukan diskusi dalam suasana yang lebih nyaman, menyenangkan dan media yang digunakan mendukung sehingga siswa senang untuk belajar. Kendala yang dihadapi adalah membutuhkan waktu yang lebih di awal pertemuan untuk mengenalkan kepada siswa mengenai media Edmodo karena di kelas VII kebanyakan siswa baru mengenal android maupun aplikasi edmodo. Guru dituntut untuk selalu memantau jalannya proses pembelajaran.

\section{KESIMPULAN}

Berdasarkan analisis data dapat disimpulkan bahwa thitung sebesar 5,539 dengan $\mathrm{dk}=61$, taraf signifikansinya kurang dari 0,05 maka diperoleh $\mathrm{t}_{\text {tabel }}$ sebesar 2,000, maka $\mathrm{H}_{1}$ diterima. Ini berarti bahwa ada pengaruh penggunaan media Edmodo sebagai basis e-learning terhadap motivasi belajar siswa pada mata pelajaran IPA siswa kelas VII.

\section{UCAPAN TERIMAKASIH}

Penulis ingin mengucapkan terimakasih kepada semua pihak yang telah memberikan dukungan finansial dan moral untuk penelitian ini.

\section{DAFTAR PUSTAKA}

[1] Aqib, Z. 2013. Model-Model, Media, dan Strategi Pembelajaran Konstektual (Inovatif). Bandung: Yrama Widya.

[2] Basori. 2013. Pemanfaatan Social Learning Network Edmodo dalam Membantu Perkuliahan Teori Bodi Otomotif di Prodi PTM JPTK FKIP UNS. JIPTEK, (21) : 99-105.

[3] Khodijah, N. 2011. Psikologi Pendidikan. Palembang: Grafika Telindo Press.

[4] Prawiradilaga, dkk. 2013. Mozaik Teknologi Pendidikan e-Learning. Jakarta: Prenada Media.

[5] Sardirman, A.M. 2005. Interaksi Belajar Mengajar. Jakarta: Rajawali.

[6] Sastroprawiro, W. N. 2011. The Missing Abundance Mentality in Our Curriculum dalam Seri Pemikiran Mahasiswa: Ekonomi Indonesia di Mata Anak Muda UI. FE UI: Baduose Media.

[7] Sugiyono, 2013. Metode Penelitian Pendidikan. Pendekatan Kuantitatif Kualitatif, dan $R \& D$. Bandung: Alfabeta.

[8] Sugiyono. 2015. Metode Penelitian Kombinasi (Mixed Methods). Bandung: Alfabeta.

[9] Suriadhi, G., dkk. 2014. Pengembangan eLearning Berbasis Edmodo pada Mata Pelajaran IPA Kelas VIII di SMPN 2 Singaraja. Jurnal Edutech Universitas Pendidikan Ganesha Jurusan Teknologi Pendidikan, 2 (1) : 1-10.

[10] Uno, B. 2014. Teori Motivasi dan Pengukuran. Jakarta: Bumi Aksara.

[11] Yazdi, M. 2012. E-Learning sebagai Media Pembelajaran Interaktif Berbasis Teknologi Informasi. E-Jurnal Ilmiah Foristek, 2 (1) :110. 